\title{
COMPUTATIONAL INVESTIGATION OF METHYL $\alpha$-D-GLUCOPYRANOSIDE DERIVATIVES AS INHIBITOR AGAINST BACTERIA, FUNGI AND COVID-19 (SARS-2)
}

\author{
SARKAR M. A. KAWSAR ${ }^{l^{*}}$ AND AJOY KUMER ${ }^{2}$ \\ ${ }^{1}$ Laboratory of Carbohydrate and Nucleoside Chemistry, Department of Chemistry, Faculty of Science, University of Chittagong, Chittagong-4331, Bangladesh . \\ ${ }^{2}$ Department of Chemistry, European University of Bangladesh, Dhaka-1216, Bangladesh.
}

\begin{abstract}
For employing computational tools for drug discovery in the area of medicinal chemistry by carbohydrates, methyl $\alpha$-D-glucopyranoside and its ten acylated derivatives have picked up. At first, the HOMO, LUMO, and its energy gap have been obtained by the DFT method, as well as the chemical reactivity and global descriptors, such as global softness, electron affinity, ionization potential, electronegativity, global hardness, global electrophilicity index, and chemical potential have calculated from HOMO and LUMO data. From this data, it is illustrated that the HOMO-LUMO energy gap is -9.756 to $-7.756 \mathrm{kcal} / \mathrm{mol}$ while the compound 12 shows the highest energy gap and compound 10 is opposite, and the softness has recorded the range from 0.208 to 0.255 , showing a small difference, while the lower softness is picked up for 12, but $\mathbf{0 9}$ is reverse. The key and vital part of this study are noted as molecular docking against four pathogens proteins, such as Bacillus cereus, E Coli, Lanosterol 14alpha demethylase, SARS-02, and it is obtained the most expected and impactful result as an inhibitor. It is mentioned that the result of molecular docking score is $\mathbf{- 9 . 6}$ for compounds $\mathbf{0 9}$ and $\mathbf{1 1}$ against Bacillus cereus which is the highest score. But it is slightly different for E Coli -9.5 and -9.3 of compounds $\mathbf{1 0}$ and $\mathbf{0 7}$. On the other hand, it is precious and lavish work against COVID-19 protein whereas all of the tested compounds can show good and standard inhibitor with value more than -6.0 , and the $-9.1,9.0$, and 8.5 for compounds $\mathbf{0 9}, \mathbf{0 7}$, and $\mathbf{0 8}$, respectively. It may be revealed that methyl $\alpha$-D-glucopyranoside and its ten acylated derivatives are also found as a good inhibitor against SARS-02 protein than bacteria and fungi. Moreover, all of these are non-carcinogenic and low toxic in the case of both aquatic and non-aquatic species which says us for safe use in drug discovery.
\end{abstract}

Keywords: Glucopyranoside, ADMET, Molecular Docking, Drug-likeness, Toxicity, Amino Acids.

\section{INTRODUCTION}

In the contemporary era, computational chemistry is the most demanded and growing research tool to design molecules, reaction mechanisms, reaction kinetics, as well as drug design due to enormous merits. First of all, it had been established that density functional theory (DFT) [1], which was initiated by Walton Kohn in 1990 for getting more accurate magnitudes of electronic and nuclear structure for the many-body system [2], is one of the most use functional to give the accurate result of molecular systems [3,4]. Moreover, DFT has been employing to predict the structural correlation in terms of HOMO and LUMO which indicate the chemical stability and chemical reactivity of organic molecules [5-11]. Besides, molecular modeling has gained the most trust as a guide to the chemist, biochemist, pharmacist, and scientist for drug design, and it contributes to the indulgence of the biochemical functions of an organic molecule with protein by interaction and forming various week bonds $[12,13]$. The alternative area of molecular modeling techniques implies that the reaction environment for organic, inorganic, and bio-molecules through both chemical and biological systems. In the last couple of decades; this area has achieved huge attention of researchers for various studies, especially drug design and theoretical investigation of bioactive molecules through DFT and other functional. Because its most tremendous advantages belong to two specific tasks. The first and foremost application of molecular modeling is to save time consumption which has been spent in the laboratory for conducting various experimental procedures to develop drugs for initiation. For example, for developing drugs, there have conducted various tests through laboratory and ensuring these tests a drug candidate has selected for further analysis that requires at least three to five years for preselecting a candidate of the drug. During this test, if any procedure would have failed to conduct in the laboratory, there would loss of the full time passed for tests. Another issue of during test, there was used a huge amount of chemicals and materials with manpower which deals a costly matter for any discoverer or researcher besides it has a bad impact on both of aquatic and non-aquatic environment if these materials had thrown after use. For the mentioned causes, the area of computational chemistry has been rapidly rising with accurate results what is why molecular modeling has used in this study.

Molecular docking is one of the most important tools of molecular modeling of drug discovery. Because it can give them information that how a drug can be attached with the protein of pathogens and how much energy is formed or regenerated in time of binding. In addition, it can predict where the site of protein has been selected for binding and where it's pocket. Several programs have been used for molecular docking calculation, such as DOCK-6, FlexX, GLIDE, GOLD, FRED, Autodock Vina, and SURFLEX [14]. Before the last decade of the past millenniums, the major issues were only leaded by the chemical synthesis of drug-like molecules [15], the emergence of combinatorial chemistry
[16], gene technology, [17] and high-throughput tests have shifted the focus. On the other hand, poor absorption, distribution, metabolism, and excretion (ADME) properties of new drugs have captured more attention [18]. Regarding the safe use, both aquatic and non-aquatic toxicity profiles are urgent where lipophilicity is of them and has an important role in drug discovery [19]. This study has also included the ADME and toxicity of used molecules.

The wondering and dynamics area for medicinal chemistry was explored by the carbohydrates compounds and their derivatives which were used and approved drugs against antibacterial [20], antifungal [21], antitumor [22], antiviral [23], anti-diabetic [24], anti-inflammatory [25,26], antineoplastic and antiprotozoal of human and phytopathogenic micro-organisms [27]. In recent years, Kawsar et al. 2012-2019 reported various acylated monosaccharide and their derivatives [28-30] which were investigated as a broad spectrum biological activities while Kabir et al., 2005 proposed a similar topic at an earlier time in this area [31]. Regarding this vast and significant application in biological sciences, especially medicinal chemistry, acylated monosaccharide, and its derivates have selected for computational studies with its structure-activity relationship (SAR) because there are almost no data even investigation of computational chemistry although there are few profiles of experimental data to estimate these as drugs. To illustrate their biological background against bacteria, fungi even COVID-19 pathogens, the molecular docking, chemical descriptor as well as ADMET properties have employed which are constructive and indispensable for drug discovery. At a time, the aquatic and non-aquatic toxicity have evaluated using theoretical investigation.

\section{COMPUTATIONAL DETAILS}

\subsection{Preparation of ligands and evaluation of chemical reactivity}

For optimization of the structure, calculation of vibrational frequency, and molecular orbital for molecules, the most common functional DFT was employed for calculations [32-34]. The Gaussian 16W software package [35] The Gauss View 6.0.16 software was used for visualization. The VAMP code of material studio was used for optimization and calculation with analysis based on DFT [36,37]. After optimization, the optimized structure had imputed as a pdb file for molecular docking as a ligand.

\subsection{Molecular docking}

The crystal structure of the protein was taken from the RSCB Protein Data Bank. Then the crystal structure of the protease was optimized and checked by PyMOL version 2.1 based on their least energy and removed water molecules. Some significant factors, such as improper bond order, side-chain geometry, and 
missing hydrogen were observed in the crystal structure of the protease even heteroatom [38]. Finally, the nonbonding interaction of antivirus drug-protease was calculated using the Autodock Vina software package for the docking analysis [39]. Molecular docking studies were performed PyRx and AutoDock Vina Wizard with the flexible ligand and the rigid receptor. The visualization was performed by using Discovery Studio [40].

\subsection{Analysis of ADME, physicochemical and pharmacokinetics}

ADME stands for absorption, distribution, metabolism, and Excretion. For calculating this parameter, an online database named admetSAR was used [41].
On the other hand, the Lipinski rule was predicted using another online database http://www.swissadme.ch/index.php which data predicts the pharmacokinetics, drug-likeness and medicinal chemistry friendliness [42].

\section{RESULTS AND DISCUSSIONS}

\subsection{Optimized structure}

The methyl $\alpha$-D-glucopyranoside and its derivatives were simulated by computational tools through the DFT method and the optimized chemical structures of studies compounds are listed in Figure 1.

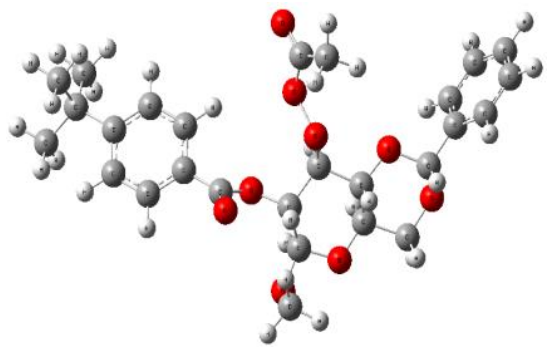

Methyl 3-0-acetyl-4,6-O-benzylidene-2-O-(4-tbutylbenzoyl)- $\alpha$-D-glucopyranoside [03]

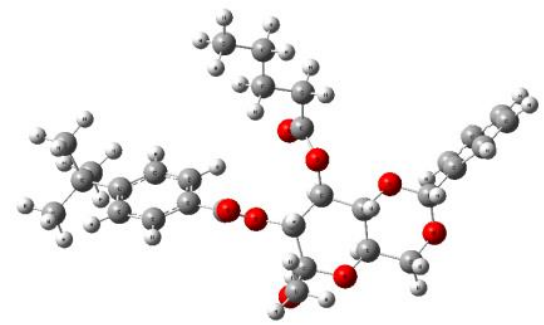

Methyl 4,6-O-benzylidene-2-O-(4-t-butylbenzoyl)3-O-pentanoyl- $\alpha$-D-glucopyranoside [04]

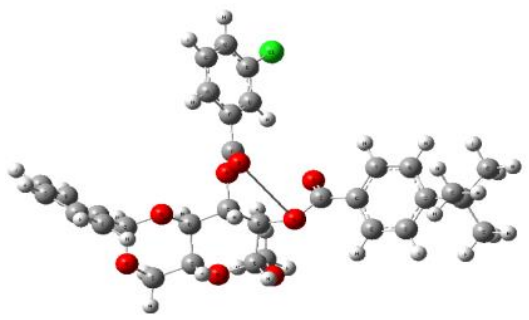

Methyl 4,6-O-benzylidene-2-O-(4-t-butylbenzoyl)3-O-(3-chlorobenzoyl)- $\alpha$-D-glucopyranoside [07]

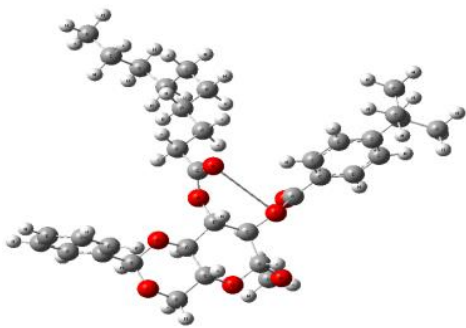

Methyl 4,6-O-benzylidene-2-O-(4-tbutylbenzoyl)-3-O-decanoyl- $\alpha$-Dglucopyranoside [05]

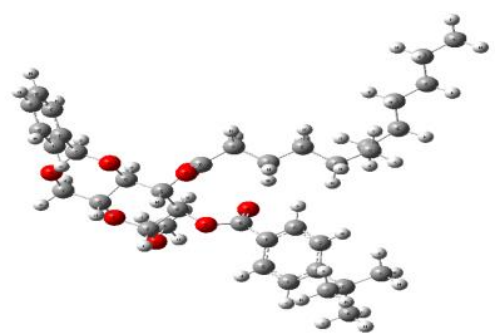

Methyl 4,6-O-benzylidene-2-O-(4-tbutylbenzoyl)-3-O-lauroyl- $\alpha$-Dglucopyranoside [06]

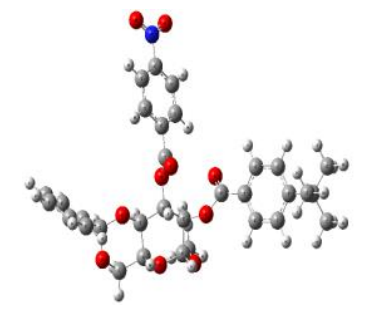

Methyl 4,6-O-benzylidene-2-O-(4t-butylbenzoyl)-3-O-(4nitrobenzoyl)- $\alpha$-Dglucopyranoside [09]

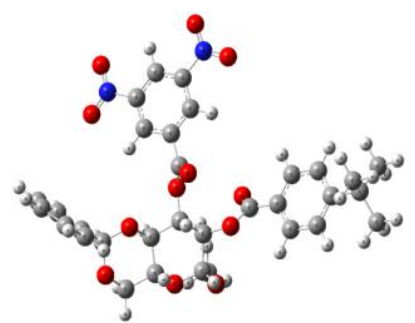

Methyl 4,6-O-benzylidene-2-0-(4-tbutylbenzoyl)-3-0-(3,5dinitrobenzoyl)- $\alpha$-D-glucopyranoside [10]

Figure 1. Optimized structure of compounds.

\subsection{Chemical reactivity and global descriptors}

HOMO is the short form of and highest occupied molecular orbital and the lowest unoccupied molecular orbital is denoted by LUMO, which are considered substantial orbitals of frontier molecular orbitals (FMOs). Usually, the HOMO contains the enriched electron and it can be capable of donating an electron to another. In the drug discovery, the HOMO influence a great deal for ligand because the higher value of HOMO for ligand are highly capable of transferring their electron to protein or enzyme though which the interacting bond and binding affinity are introduced between them $[6,8,10,43,44]$. For this reason, the LUMO is of the same importance as protein but in this study, the main concentration of HOMO, LUMO belongs to only ligand molecules.

Secondly, the key importance of HOMO, LUMO is used for calculating the energy gap between two levels and noted that the lower energy gap introduces the higher chemical reactivity and lower chemical stability. The lower chemical

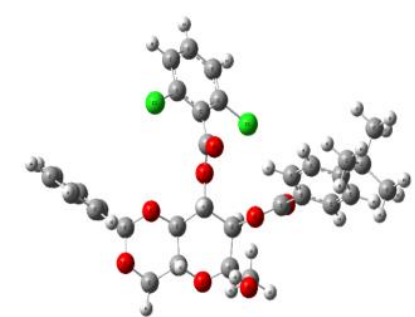

Methyl-4,6-O-benzylidene-2-O-(4-tbutylbenzoyl)-3-O-(2,6dichlorobenzoyl)- $\alpha-\mathrm{D}$ glucopyranoside [11]

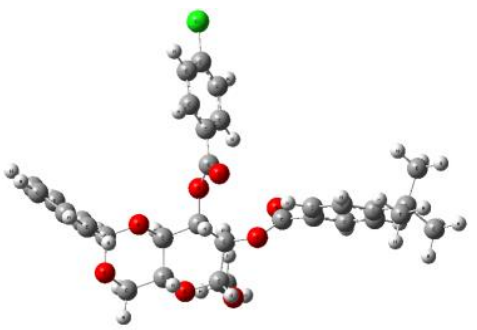

Methyl 4,6-O-benzylidene-2-O-(4-tbutylbenzoyl)-3-O-(4-chlorobenzoyl)- $\alpha$-Dglucopyranoside [08]

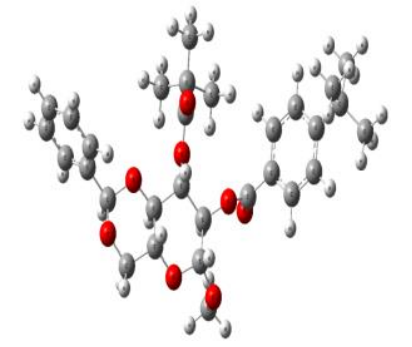

Methyl 4,6-O-benzylidene-2-O-

(4-t-butylbenzoyl)-3-O-pivaloyl$\alpha$-D-glucopyranoside [12] stable molecule can be easily dissociated which is further conducted the global reactivity descriptors, such as global softness $(S)$, electron affinity $(A)$, ionization potential $(I)$, electronegativity $(X)$, global hardness $(\eta)$, global electrophilicity index $(\omega)$ and chemical potential $(\mu)$ calculated utilizing equations [34,45,46]. All these parameters are calculated by following equations and listed in Table 1 .

$$
\begin{aligned}
& \mathrm{E}_{\text {gap }}=\left(\mathrm{E}_{\text {LUMO }}-\mathrm{E}_{\text {Hомо }}\right) \\
& I=-E_{\text {HOMO }} \\
& A=-E_{\text {LUMO }} \\
& (\mu)=-\frac{I+A}{2} \\
& (\eta)=\frac{I-A}{2} \\
& (S)=\frac{1}{\eta} \\
& (\chi)=\frac{I+A}{2} \\
& (\omega)=\frac{\mu^{2}}{2 \eta}
\end{aligned}
$$


Table 1. Descriptors for chemical reactivity.

\begin{tabular}{|c|c|c|c|c|c|c|c|c|c|c|}
\hline $\mathbf{N}^{\circ}$ & LUMO, eV & $\begin{array}{l}\text { HOMO, } \\
\text { eV }\end{array}$ & $\begin{array}{l}\text { HOMO } \\
\text { LUMO } \\
\text { gap, eV }\end{array}$ & $\begin{array}{c}\text { Ionization } \\
\text { potential } \\
\text { (I), eV } \\
\end{array}$ & $\begin{array}{l}\text { Electron } \\
\text { affinity } \\
\text { (A), eV }\end{array}$ & $\begin{array}{c}\text { Chemical } \\
\text { potential } \\
(\mu) \mathrm{eV} \\
\end{array}$ & $\begin{array}{l}\text { Hardness, } \\
(\eta), \mathrm{eV}\end{array}$ & $\begin{array}{l}\text { Electronegativity, } \\
\qquad(\chi), \mathbf{e V}\end{array}$ & $\begin{array}{l}\text { Electrophilicity } \\
(\omega), \mathrm{eV}\end{array}$ & $\begin{array}{l}\text { Softness, } \\
(\mathrm{S}), \mathrm{eV}\end{array}$ \\
\hline 03 & -0.326 & -9.823 & 9.497 & -9.823 & -0.326 & 5.074 & -4.748 & -5.074 & -2.711 & -0.210 \\
\hline 04 & -0.299 & -9.768 & 9.469 & -9.768 & -0.299 & 5.0335 & -4.734 & -5.033 & -2.675 & -0.211 \\
\hline 05 & -0.318 & -9.768 & 9.450 & -9.768 & -0.318 & 5.043 & -4.725 & -5.043 & -2.692 & -0.211 \\
\hline 06 & -0.272 & -9.687 & 9.415 & -9.687 & -0.272 & 4.979 & -4.707 & -4.979 & -2.633 & -0.212 \\
\hline 07 & -0.408 & -9.523 & 9.115 & -9.523 & -0.408 & 4.965 & -4.557 & -4.965 & -2.705 & -0.219 \\
\hline 08 & -0.517 & -9.632 & 9.115 & -9.632 & -0.517 & 5.074 & -4.557 & -5.074 & -2.825 & -0.219 \\
\hline 09 & -1.414 & -9.251 & 7.837 & -9.251 & -1.414 & 5.332 & -3.918 & -5.332 & -3.628 & -0.255 \\
\hline 10 & -2.040 & -9.796 & 7.756 & -9.796 & -2.040 & 5.918 & -3.878 & -5.918 & -4.515 & -0.257 \\
\hline 11 & -0.544 & -9.251 & 8.707 & -9.251 & -0.544 & 4.897 & -4.353 & -4.897 & -2.754 & -0.229 \\
\hline 12 & -0.166 & -9.742 & 9.576 & -9.742 & -0.166 & 4.954 & -4.788 & -4.954 & -2.562 & -0.208 \\
\hline
\end{tabular}

\subsection{Frontier molecular orbital of HOMO and LUMO}

Figure 2, it has presented the frontier orbital diagram of HOMO and LUMO by different colors for well understanding. In the case of HOMO, the deep radish color denotes the positive nodes and the yellow color is to a negative node of orbitals. In contrast, green color carries the negative part of the orbital, and maroon color indicates the positive part of the orbital. All other molecules are obtainable and accessible in Figure 2 with a particular color map. It is notified that the HOMO is mapped in the part of the last end of the benzene ring part of the sample which causes might be explained the aromatic ring resonance. In the around acylated group, the LUMO is found which has created the presence of oxygen atom.

03

04

05
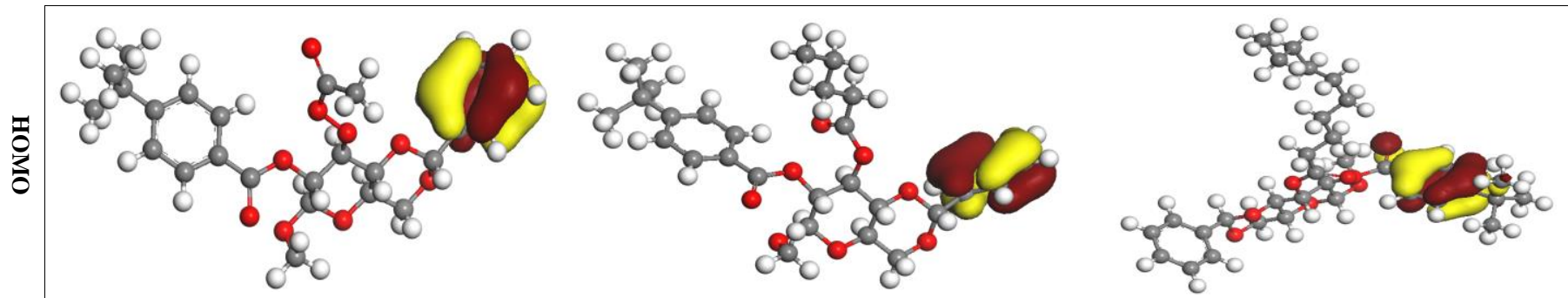

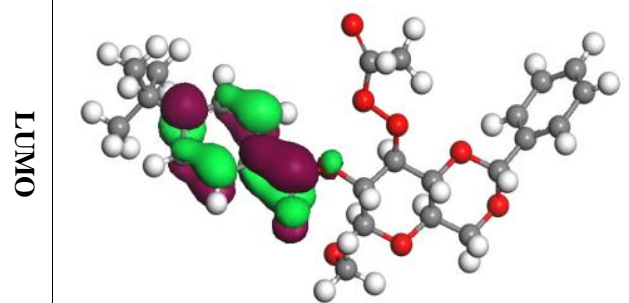

06
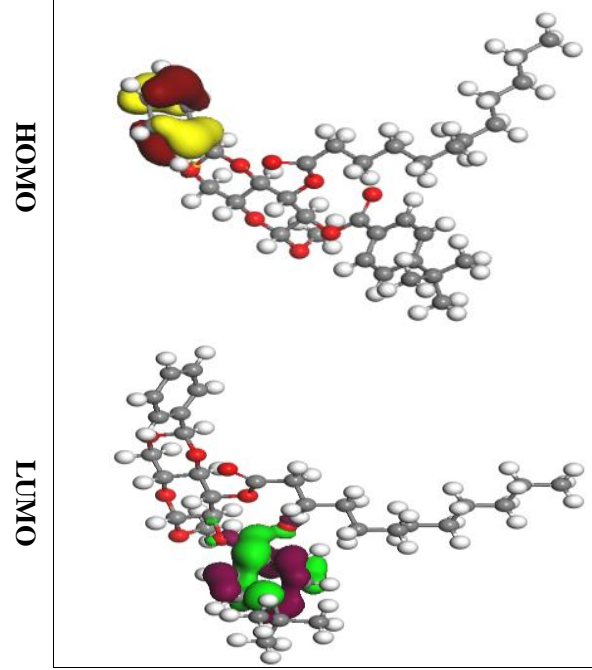

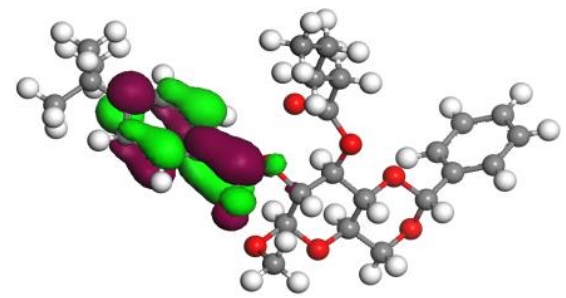

07
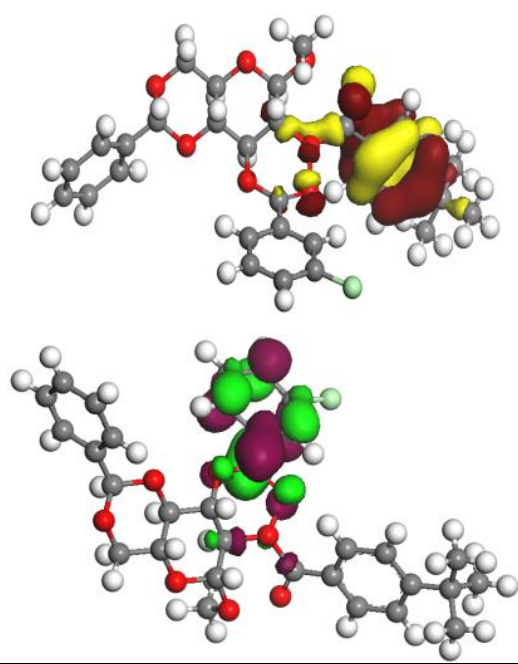

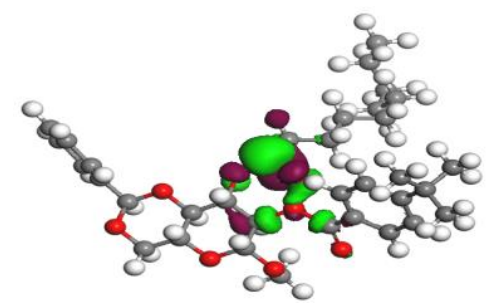

08
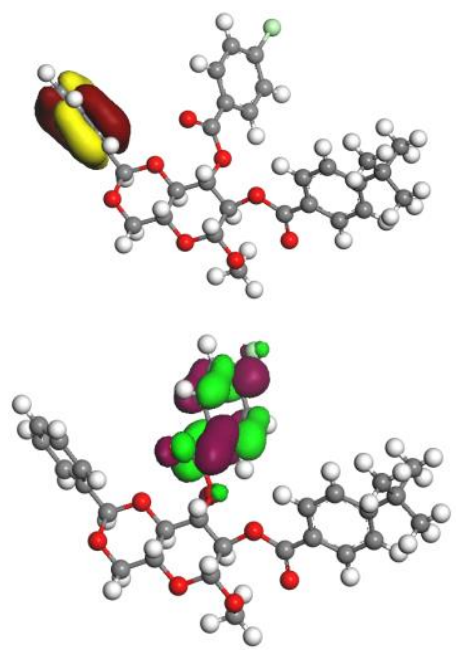
09

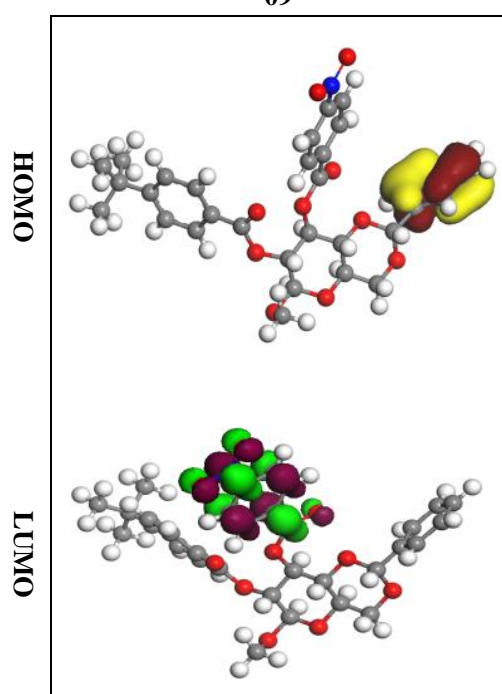

10
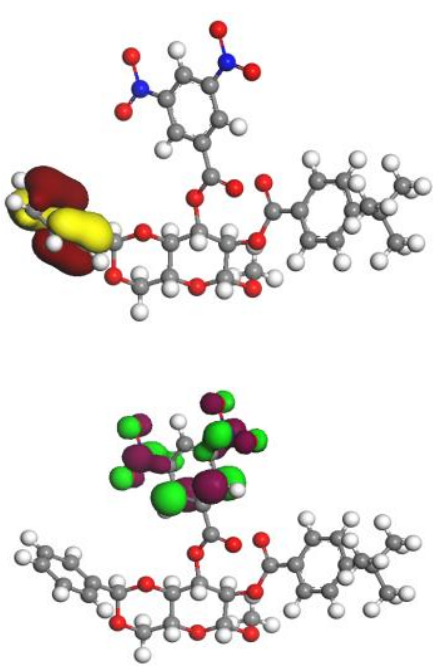

11
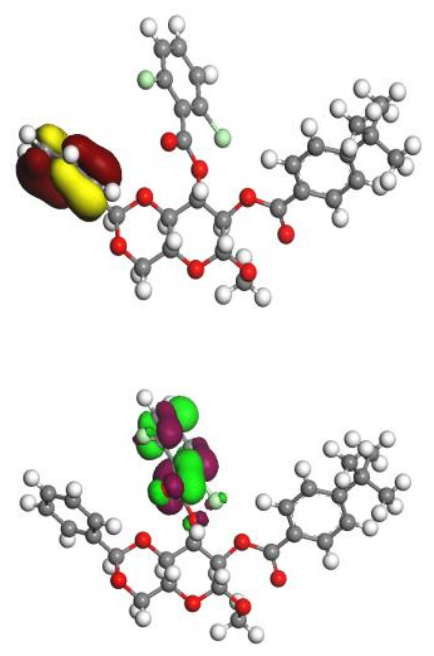

12
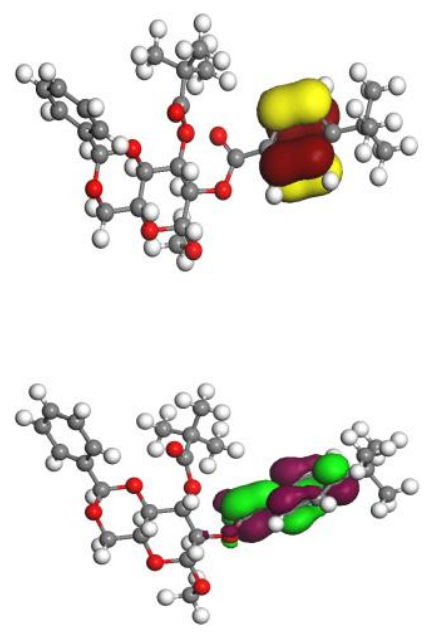

Figure 2. Frontier Molecular orbital of HOMO and LUMO.

\subsection{Molecular docking and binding energy}

Docking results are usually expressed by the binding affinity of a drug, as well as the active site of the pathogen's protein with that other drug, and the number of hydrogen bonds, hydrophobic bonds, polar and non-polar, where they are linked. Polar bonding usually occurs with a ligand partially charged atom with a protein molecule with a partially charged atom. Table 2 presents the different types of hydrogen bonding numbers and the skeletons of amino acids that are usually polar bonds and the higher the number of these bonds, the higher the binding affinity value. Table 2 shows that the number of hydrogen bonds is not the same for every drug. The highest binding energy has been found in compound 09 in all cases of bacteria, fungi, and viruses.

Table 2. Molecular docking score against pathogens.

\begin{tabular}{|c|c|c|c|c|c|c|c|c|c|c|c|c|}
\hline & \multicolumn{3}{|c|}{ Bacillus cereus } & \multicolumn{3}{|c|}{ E Coli } & \multicolumn{3}{|c|}{ Lanosterol 14alpha demethylase } & \multicolumn{3}{|c|}{ SAR-02 } \\
\hline $\mathbf{N}^{\circ}$ & $\begin{array}{l}\text { Binding } \\
\text { Affinity }\end{array}$ & $\begin{array}{c}\text { No. of } \mathrm{H} \\
\text { bond }\end{array}$ & $\begin{array}{c}\text { No. of } \\
\text { Hydrophobic } \\
\text { bond }\end{array}$ & $\begin{array}{l}\text { Binding } \\
\text { Affinity }\end{array}$ & $\begin{array}{c}\text { No. of } \mathbf{H} \\
\text { bond }\end{array}$ & \begin{tabular}{|c|} 
No. of \\
$\begin{array}{c}\text { Hydrophobic } \\
\text { bond }\end{array}$ \\
\end{tabular} & $\begin{array}{l}\text { Binding } \\
\text { Affinity }\end{array}$ & $\begin{array}{l}\text { No. of } \mathbf{H} \\
\text { bond }\end{array}$ & $\begin{array}{c}\text { No. of } \\
\text { Hydrophobic } \\
\text { bond }\end{array}$ & $\begin{array}{l}\text { Binding } \\
\text { Affinity }\end{array}$ & $\begin{array}{c}\text { No. of } \mathrm{H} \\
\text { bond }\end{array}$ & \begin{tabular}{|c|} 
No. of \\
$\begin{array}{c}\text { Hydrophobic } \\
\text { bond }\end{array}$ \\
\end{tabular} \\
\hline 3 & -8.2 & 0 & 4 & -8.8 & 1 & 3 & -8.5 & 1 & 4 & -7.8 & 1 & 4 \\
\hline 4 & -7.3 & 1 & 5 & -7.9 & 3 & 5 & -8.1 & 7 & 4 & -6.9 & 7 & 4 \\
\hline 5 & -7.9 & 3 & 1 & -7.9 & 3 & 4 & -9.5 & 1 & 8 & -6.9 & 1 & 8 \\
\hline 6 & -6.8 & 4 & 4 & -7.3 & 3 & 0 & -6.9 & 1 & 8 & -6.1 & 1 & 8 \\
\hline 7 & -8.1 & 5 & 2 & -9.3 & 5 & 2 & -9.9 & 2 & 3 & -9.0 & 2 & 3 \\
\hline 8 & -8.3 & 3 & 3 & -9.2 & 3 & 3 & -8.7 & 2 & 3 & -7.9 & 2 & 3 \\
\hline 9 & -9.6 & 3 & 5 & -9.2 & 2 & 4 & -10.2 & 0 & 11 & -9.1 & 1 & 11 \\
\hline 10 & -8.7 & 3 & 1 & -9.5 & 4 & 2 & -9.4 & 1 & 3 & -8.5 & 1 & 3 \\
\hline 11 & -9.6 & 2 & 6 & -8.7 & 5 & 4 & -9.3 & 3 & 5 & -7.6 & 3 & 5 \\
\hline 12 & -8.9 & 3 & 2 & -8.6 & 3 & 3 & -7.8 & 1 & 9 & -7.3 & 1 & 9 \\
\hline
\end{tabular}

From the Figure-3, it is illustrated the molecular docking interaction of 09 molecules with Bacillus cereus protein. Figure 3(a), there is attached the protein ligands interaction which was taken in the discovery studio. Figure 3(b) presents the 2D interaction between ligands and protein with how the type of bonding occurred between them and bond distance. Figures 3(c) and 3(d) provide information on hydrogen bonding and hydrophobic interaction with their scaling. From the hydrogen bonding of Figure 3(c), it might be concluded that the donor and acceptor are corresponding to each other with equal magnitudes. In the case of hydrophobic interaction, the negative scale (-3.0) is observed as a higher portion than the other part.

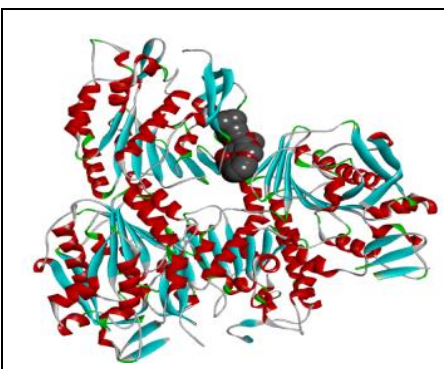

a) Lignad in pocket of protein

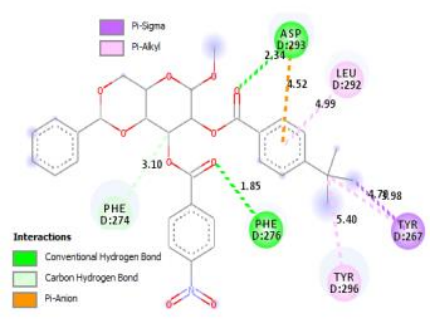

b) $2 \mathrm{D}$ diagram for interaction of lignad with protein

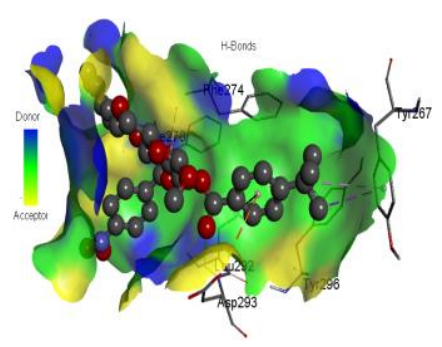

c) Hydrogen bonding

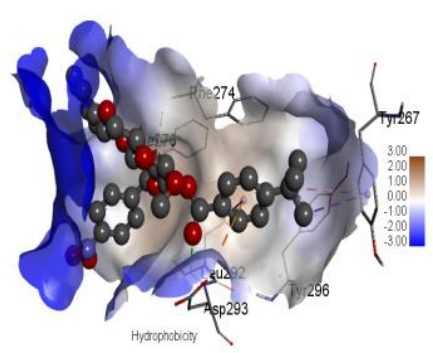

d) Hydrophobic interaction

Figure 3. Molecular docking interaction of 09 molecules with Bacillus cereus protein. 


\subsection{Drug like properties}

Molecular properties for drugs, like membrane permeability and bioavailability of lead compounds, depend on some basic properties of molecules, such as partition coefficient $(\log \mathrm{P})$, molecular weight $(\mathrm{MW})$, and a number of hydrogen bond acceptors/donors that are associated with Lipinski rule of five [47] shown Table 3. It shows all compounds followed the rule of five indicating the good bioavailability of molecules. The drug-likeness score of lead molecules is determined with a combination of GPCR, ion channel modulator, a kinase inhibitor, nuclear receptor ligands, protease inhibitor, and enzyme inhibitor, which has been applied to investigate the efficiency of molecules to qualify for drug development. Srivastava et al. (2015) elucidated that the larger the bioactivity score has the higher probability of the specific molecule being active. If the bioactivity score of the molecule is greater than 0.00 , has considerable biological activities and scores between 0.50 to 0.00 are considered to be moderately active and if the value is less than 0.50 it is presumed to be inactive [48]. The obtained values of the drug-likeness score revealed that all compounds show good drug-likeness along with other standard drugs.

Table 3. Data of Lipinski rule, pharmacokinetics, and drug-likeness

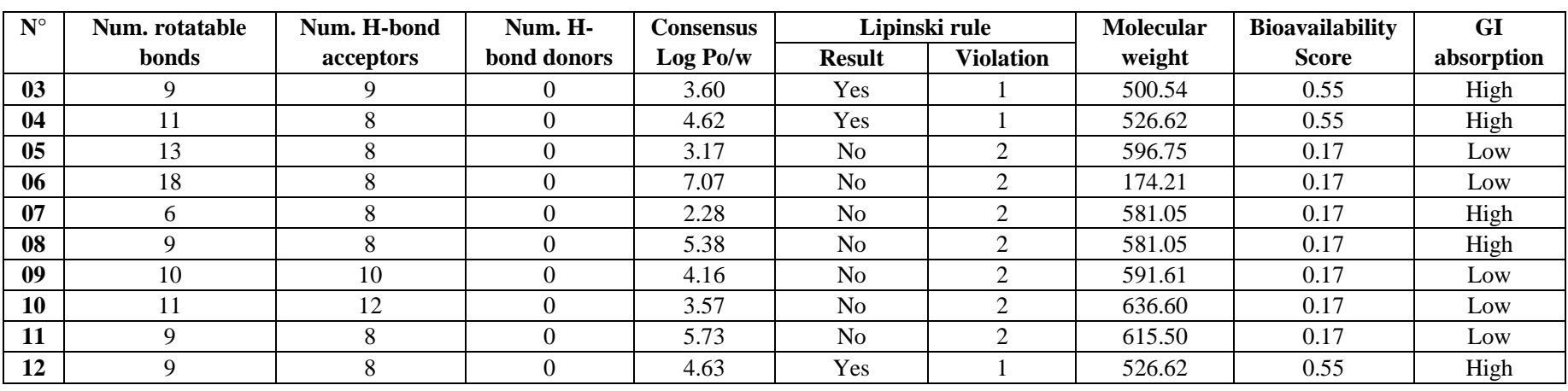

\subsection{Pharmacokinetic of the best photochemical materials}

Total ten pharmacokinetic parameters including human intestinal absorption, blood-brain barrier, human oral bioavailability, carcinogenicity (binary), fish aquatic toxicity, water-solubility, acute oral toxicity, and Tetrahymena pyriformis sp, IGC50, are tested for the ten molecules. The results are summarized in Table 4 which includes some pharmacokinetics parameters. The results show that the Methyl $\alpha$-D-glucopyranoside and its derivatives are safer to uses. From Table 4, compound $\mathbf{0 7}$ shows the potential activity of cancer, but all others are zero or non-carcinogenic compounds.

Table 4. Pharmacokinetic parameters of the best photochemical materials

\begin{tabular}{|c|c|c|c|c|c|c|c|c|}
\hline$\underset{\circ}{\mathbf{N}}$ & $\begin{array}{c}\text { Human Intestinal } \\
\text { Absorption } \\
\text { (+ve/-ve) }\end{array}$ & $\begin{array}{c}\text { Blood Brain } \\
\text { Barrier } \\
\text { (+ve/-ve) }\end{array}$ & $\begin{array}{c}\text { Human oral } \\
\text { bioavailability } \\
\text { (+ve/-ve) }\end{array}$ & $\begin{array}{c}\text { Carcinogenicity } \\
\text { (binary) } \\
\text { (+ve/-ve) }\end{array}$ & $\begin{array}{c}\text { Fish aquatic } \\
\text { toxicity } \\
\text { (+ve/-ve) }\end{array}$ & $\begin{array}{c}\text { Water } \\
\text { solubility } \\
\operatorname{logS}\end{array}$ & $\begin{array}{l}\text { Acute Oral Toxicity } \\
\qquad(\mathrm{kg} / \mathrm{mol})\end{array}$ & $\begin{array}{c}\text { Tetrahymena } \\
\text { pyriformis } \\
\text { pIGC50 (ug/L) }\end{array}$ \\
\hline 03 & + & + & - & - & + & -3.845 & 3.343 & 1.018 \\
\hline 04 & + & + & - & - & + & -4.422 & 3.284 & 1.369 \\
\hline 05 & + & + & - & - & + & -8.00 & 0.471 & 1.488 \\
\hline 06 & + & + & - & - & + & -5.125 & 3.306 & 1.364 \\
\hline 07 & + & + & - & Danger & + & -7.36 & 0.574 & 1.105 \\
\hline 08 & + & + & - & - & + & -4.561 & 3.174 & 1.237 \\
\hline 09 & + & + & - & - & + & -3.914 & 3.37 & 1.226 \\
\hline 10 & + & + & - & - & + & -4.065 & 3.357 & 1.268 \\
\hline 11 & + & + & - & - & + & -4.681 & 3.522 & 1.429 \\
\hline 12 & + & + & - & - & + & -3.788 & 3.106 & 0.956 \\
\hline
\end{tabular}

\subsection{Evaluation of ADME properties}

For drug discovery, the ADME is the most important to understand for perfect evaluation of various biological phenomena [49]. Among them, active efflux is initiated through the biological membrane, such as from the gastrointestinal wall to the lume, which is performed by substrate or non-substrate of the Caco- 2 permeability, almost having negative value except 05 and 07 or skin permeability, showing a good magnitude. However, the BSEP inhibitor is recorded as the yes value but an opposite trend is found for OCT2 inhibitor (Table 5). On the other hand, the other vital parameters for ADME are a bloodbrain barrier, plasma protein binding, thyroid receptor binding which have the accepted level of value.

Table 5. Data of ADME properties.

\begin{tabular}{|c|c|c|c|c|c|c|c|}
\hline $\mathbf{N}^{\circ}$ & $\begin{array}{c}\text { Caco-2 } \\
\text { permeability }(\mathrm{log} \\
\left.\text { Papp in } 10^{-6} \mathrm{~cm} / \mathrm{s}\right)\end{array}$ & \begin{tabular}{l}
\multicolumn{1}{c}{ Skin } \\
permeation \\
$(\log K p), \mathrm{cm} / \mathrm{s}$
\end{tabular} & $\begin{array}{c}\text { Blood Brain } \\
\text { Barrier }\end{array}$ & $\begin{array}{c}\text { Plasma protein } \\
\text { binding }\end{array}$ & $\begin{array}{l}\text { Thyroid } \\
\text { receptor } \\
\text { binding }\end{array}$ & $\begin{array}{c}\text { OCT2 inhibitor } \\
\text { (Yes/No) }\end{array}$ & BSEP inhibitor \\
\hline 3 & - & -6.240 & 0.929 & 0.954 & 0.668 & No & Yes \\
\hline 4 & - & -5.450 & 0.939 & 0.926 & 0.664 & No & Yes \\
\hline 5 & + & -4.170 & 0.850 & 0.941 & 0.613 & No & Yes \\
\hline 6 & - & -3.360 & 0.948 & 0.966 & 0.511 & No & Yes \\
\hline 7 & + & -5.350 & 0.720 & 0.987 & 0.577 & No & Yes \\
\hline 8 & - & -5.140 & 0.958 & 1.095 & 0.674 & No & Yes \\
\hline 9 & - & -5.760 & 0.962 & 1.018 & 0.680 & No & Yes \\
\hline 10 & - & -6.160 & 0.966 & 1.044 & 0.707 & No & Yes \\
\hline 11 & - & -4.900 & 0.951 & 1.199 & 0.633 & No & Yes \\
\hline 12 & - & -5.430 & 0.870 & 0.939 & 0.717 & No & Yes \\
\hline
\end{tabular}




\subsection{Aquatic and non-aquatic toxicity}

Human pharmaceutical leads a heavy risk after using the active pharmaceutical ingredients (APIs) which enter the environment primarily after excretions from patient's bodies into the aquatic and non-aquatic environment even it has also mixed with these compositions of the environment from the manufacturing process and testing in a research laboratory in preparing progress [50]. That is why; it is the urgent need for the test of aquatic and non-aquatic by these compositions for safe our ecology from harmful effect. It is an alarming result for the aquatic environment by these acylated compounds that they are highly sensitive and attractive affinity for fish species, as well as oral rat acute, AMES toxicity, honey bee toxicity, and T. Pyriformis toxicity (Table 6). Therefore, this toxicity study gives us information that it might be careful with use regarding environmental issues.

Table 6. Aquatic and non-aquatic toxicity

\begin{tabular}{|c|c|c|c|c|c|c|c|c|c|}
\hline $\mathbf{N}^{\circ}$ & $\begin{array}{c}\text { AMES toxicity } \\
(\text { Yes } / \text { No })\end{array}$ & \begin{tabular}{|c|} 
Human either-a- \\
go-go inhibition
\end{tabular} & Carcinogenicity & Honey Bee Toxicity & Fish Toxicity & $\begin{array}{c}\text { Acute Oral Toxicity } \\
(\mathrm{kg} / \mathrm{mol})\end{array}$ & $\begin{array}{l}\text { Oral Rat Acute Toxicity } \\
(\mathrm{LD50})(\mathrm{mol} / \mathrm{kg})\end{array}$ & \begin{tabular}{|c|} 
T. Pyriformis \\
toxicity $($ pIGC50, ug/L)
\end{tabular} & $\begin{array}{c}\text { Fish Toxicity } p L C 50, \\
m g / L\end{array}$ \\
\hline 03 & No & + & - & 0.557 & High & 3.343 & 2.680 & 0.839 & 0.270 \\
\hline 04 & No & + & - & 0.649 & High & 3.284 & 2.557 & 1.331 & 0.180 \\
\hline 05 & No & - & - & 0.697 & High & 0.471 & 2.795 & 1.488 & 0.751 \\
\hline 06 & No & - & - & 0.646 & High & 0.506 & 2.747 & 1.586 & 0.430 \\
\hline 07 & No & + & + & 0.694 & High & 0.574 & 2.661 & 1.105 & 0.254 \\
\hline 08 & No & + & - & 0.597 & High & 0.639 & 2.630 & 1.205 & -0.145 \\
\hline 09 & Yes & + & - & 0.630 & High & 0.534 & 2.715 & 1.010 & 0.665 \\
\hline 10 & No & + & - & 0.650 & High & 0.509 & 2.717 & 1.029 & 0.663 \\
\hline 11 & No & + & - & 0.543 & High & 0.621 & 2.647 & 1.277 & -0.210 \\
\hline 12 & No & + & - & 0.5985 & High & 3.10 & 2.575 & 0.925 & 0.124 \\
\hline
\end{tabular}

\subsection{Amino acid residue for hydrogen bond and hydrophobic bond interaction with bond distance}

Tables 7 and 8 represent the hydrogen bonding and hydrophobic bonding against Bacillus cereus, E coli, Lanosterol 14alpha demethylase protein with bond distance. It may be revealed that the hydrogen bond distance is smaller than the hydrophobic bond distance although the number is an inverse phenomenon.

Table 7. Hydrogen bonding and hydrophobic bonding against Bacillus cereus and E Coli.

\begin{tabular}{|c|c|c|c|c|}
\hline \multicolumn{5}{|c|}{ Bacillus cereus } \\
\hline & \multicolumn{2}{|c|}{ Hydrogen bond } & \multicolumn{2}{|c|}{ Hydrophobic bond } \\
\hline $\mathbf{N}^{\circ}$ & $\begin{array}{c}\text { Interacting residue of } \\
\text { amino acid }\end{array}$ & \begin{tabular}{|c|} 
Distance, \\
$\mathbf{A}^{\circ}$ \\
\end{tabular} & $\begin{array}{c}\text { Interacting residue of } \\
\text { amino acid }\end{array}$ & $\begin{array}{c}\text { Distance, } \\
\mathbf{A}^{\circ} \\
\end{array}$ \\
\hline 03 & Absent & Absent & $\begin{array}{l}\text { GLU-317 } \\
\text { VAL-319 } \\
\text { LYS-282 } \\
\end{array}$ & $\begin{array}{l}4.76 \\
4.53 \\
4.92 \\
\end{array}$ \\
\hline 04 & GLY-286 & 3.28 & $\begin{array}{l}\text { LEU-210 } \\
\text { GLN-285 } \\
\text { VAL-284 } \\
\text { PRO-310 } \\
\text { LYS-282 }\end{array}$ & $\begin{array}{l}4.80 \\
3.46 \\
4.71 \\
5.32 \\
5.24\end{array}$ \\
\hline 05 & $\begin{array}{l}\text { THR-280 } \\
\text { GLU-328 } \\
\text { GLU-328 }\end{array}$ & $\begin{array}{l}4.93 \\
3.70 \\
3.79\end{array}$ & VAL-319 & 4.13 \\
\hline 06 & $\begin{array}{l}\text { ASN-322 } \\
\text { TYR-236 } \\
\text { TYR-212 } \\
\text { SER-349 } \\
\text { GLY-228 }\end{array}$ & $\begin{array}{c}2.72 \\
3.75 \\
3.19 \\
3.13 \\
3.09,3.4 \\
\end{array}$ & $\begin{array}{l}\text { ASP-235 } \\
\text { LYS-271 } \\
\text { PHE-276 } \\
\text { LYS-229 }\end{array}$ & $\begin{array}{l}4.36 \\
4.57 \\
4.23 \\
5.08\end{array}$ \\
\hline 07 & $\begin{array}{c}\text { PHE-276 } \\
\text { ARG-330 } \\
\text { ASP-372 } \\
\text { ASN-275 }\end{array}$ & $\begin{array}{c}2.73 \\
2.76,2.7 \\
3.49 \\
3.75 \\
\end{array}$ & $\begin{array}{l}\text { LUE-292 } \\
\text { VAL-279 }\end{array}$ & $\begin{array}{l}4.01 \\
5.15\end{array}$ \\
\hline 08 & $\begin{array}{l}\text { ARG-330 } \\
\text { ASN-374 } \\
\text { ASN-291 }\end{array}$ & $\begin{array}{l}2.90 \\
2.72 \\
5.36\end{array}$ & $\begin{array}{l}\text { GLU-321 } \\
\text { ARG-330 } \\
\text { LEU-292 }\end{array}$ & $\begin{array}{l}4.16 \\
3.86 \\
5.12\end{array}$ \\
\hline 09 & $\begin{array}{l}\text { PHE-276 } \\
\text { ASP-293 } \\
\text { PHE-274 }\end{array}$ & $\begin{array}{l}1.85 \\
2.34 \\
3.10\end{array}$ & $\begin{array}{l}\text { ASP-293 } \\
\text { LEU-292 } \\
\text { TYR-267 } \\
\text { TYR-296 }\end{array}$ & $\begin{array}{c}4.53 \\
4.99 \\
4.79,4.98 \\
5.40\end{array}$ \\
\hline 10 & $\begin{array}{l}\text { ASN-374 } \\
\text { THR-280 } \\
\text { LYS-282 }\end{array}$ & $\begin{array}{l}2.19 \\
2.43 \\
3.73\end{array}$ & GLU-328 & 3.33 \\
\hline 11 & $\begin{array}{l}\text { ASP-293 } \\
\text { PHE-274 }\end{array}$ & $\begin{array}{l}2.57 \\
3.28\end{array}$ & $\begin{array}{l}\text { TYR-267 } \\
\text { TYR-296 } \\
\text { LEU-292 } \\
\text { VAL-279 }\end{array}$ & $\begin{array}{c}3.75,4.53 \\
5.37 \\
5.11,4.53 \\
3.95\end{array}$ \\
\hline 12 & $\begin{array}{l}\text { ASN-132 } \\
\text { ASN-376 } \\
\text { GLN-131 } \\
\end{array}$ & $\begin{array}{l}2.19 \\
1.89 \\
2.97\end{array}$ & $\begin{array}{l}\text { ASN-132 } \\
\text { VAL-319 }\end{array}$ & $\begin{array}{l}3.53 \\
4.96\end{array}$ \\
\hline
\end{tabular}

\begin{tabular}{|c|c|c|c|c|}
\hline \multicolumn{5}{|c|}{ E Coli } \\
\hline & \multicolumn{2}{|c|}{ Hydrogen bond } & \multicolumn{2}{|c|}{ Hydrophobic bond } \\
\hline $\mathbf{N}^{\circ}$ & $\begin{array}{c}\text { Interacting residue of } \\
\text { amino acid }\end{array}$ & $\begin{array}{c}\text { Distance, } \\
\mathbf{A}^{\circ}\end{array}$ & $\begin{array}{l}\text { Interacting residue } \\
\text { of amino acid }\end{array}$ & \begin{tabular}{|c} 
Distance, \\
$\mathbf{A}^{\circ}$
\end{tabular} \\
\hline 03 & ARG-386 & 2.61 & $\begin{array}{c}\text { GLU-382 } \\
\text { MET-374 } \\
\text { MET-30 }\end{array}$ & $\begin{array}{l}3.89 \\
4.70 \\
3.79\end{array}$ \\
\hline 04 & $\begin{array}{l}\text { SER-37 } \\
\text { LYR-471 } \\
\text { GLY-34 }\end{array}$ & $\begin{array}{l}2.45 \\
2.61 \\
2.41\end{array}$ & $\begin{array}{c}\text { LEU-197 } \\
\text { ASP-33 } \\
\text { VAL-15 } \\
\text { ALA-18 } \\
\text { GLU-382 }\end{array}$ & $\begin{array}{l}4.97 \\
4.40 \\
4.51 \\
4.47 \\
4.98\end{array}$ \\
\hline 05 & $\begin{array}{l}\text { SER-37 } \\
\text { LYR-471 } \\
\text { GLY-34 }\end{array}$ & $\begin{array}{l}2.38 \\
2.65 \\
2.28\end{array}$ & $\begin{array}{c}\text { ASP-33 } \\
\text { LEU-197 } \\
\text { VAL-15 } \\
\text { ALA-11 }\end{array}$ & $\begin{array}{l}4.40 \\
4.91 \\
4.97 \\
4.30\end{array}$ \\
\hline 06 & $\begin{array}{l}\text { LYR-471 } \\
\text { SER-37 } \\
\text { GLU-483 }\end{array}$ & $\begin{array}{l}2.26 \\
2.68 \\
3.72\end{array}$ & & \\
\hline 07 & $\begin{array}{l}\text { ARG-330 } \\
\text { PHE-276 } \\
\text { ASP-372 } \\
\text { ASN-275 }\end{array}$ & $\begin{array}{c}2.76,2.70 \\
2.73 \\
3.49 \\
3.75\end{array}$ & $\begin{array}{l}\text { LEU-292 } \\
\text { VAL-279 }\end{array}$ & $\begin{array}{l}4.01 \\
5.51\end{array}$ \\
\hline 08 & $\begin{array}{l}\text { ASN-374 } \\
\text { ASN-291 } \\
\text { ARG-330 } \\
\end{array}$ & $\begin{array}{l}2.91 \\
2.72 \\
5.36 \\
\end{array}$ & $\begin{array}{l}\text { GLU-321 } \\
\text { ARG-330 } \\
\text { LEU-292 }\end{array}$ & $\begin{array}{l}4.16 \\
3.86 \\
5.12 \\
\end{array}$ \\
\hline 09 & $\begin{array}{l}\text { GLN-475 } \\
\text { MET-30 }\end{array}$ & $\begin{array}{l}2.22 \\
3.56\end{array}$ & $\begin{array}{c}\text { ALA-18 } \\
\text { ARG-386 } \\
\text { LEU-197 } \\
\text { ASP-33 }\end{array}$ & $\begin{array}{l}4.03 \\
5.29 \\
5.20 \\
3.94\end{array}$ \\
\hline 10 & $\begin{array}{c}\text { TRP-437 } \\
\text { ALA-484 } \\
\text { SER-485 } \\
\text { GLU-29 }\end{array}$ & $\begin{array}{l}2.40 \\
2.69 \\
1.74 \\
3.50\end{array}$ & $\begin{array}{l}\text { ALA-18 } \\
\text { ASP-33 }\end{array}$ & $\begin{array}{l}5.40 \\
3.83\end{array}$ \\
\hline 11 & $\begin{array}{c}\text { ASP-33 } \\
\text { GLU-483 } \\
\text { ARG-386 } \\
\text { LYS-471 }\end{array}$ & $\begin{array}{c}3.49 \\
3.54 \\
2.76 \\
2.24,1.85\end{array}$ & $\begin{array}{c}\text { GLU-472 } \\
\text { MET-30 } \\
\text { LEU-197 }\end{array}$ & $\begin{array}{l}3.93 \\
4.42 \\
3.79 \\
4.55\end{array}$ \\
\hline 12 & $\begin{array}{l}\text { SER-37 } \\
\text { GLN-475 } \\
\text { SER-14 }\end{array}$ & $\begin{array}{l}2.55 \\
2.88 \\
4.67\end{array}$ & $\begin{array}{l}\text { TRP-437 } \\
\text { LYS-471 }\end{array}$ & $\begin{array}{c}4.99,5.16 \\
4.17\end{array}$ \\
\hline
\end{tabular}


Table 8. Hydrogen bonding and hydrophobic bonding against Lanosterol 14alpha demethylase.

\begin{tabular}{|c|c|c|c|c|}
\hline \multicolumn{5}{|c|}{ Lanosterol 14alph } \\
\hline & \multicolumn{2}{|c|}{ Hydrogen bond } & \multicolumn{2}{|c|}{ Hydrophobic bond } \\
\hline $\mathbf{N}^{\circ}$ & $\begin{array}{c}\text { Interacting residue of } \\
\text { amino acid }\end{array}$ & $\begin{array}{c}\text { Distance, } \\
\mathbf{A}^{\circ} \\
\end{array}$ & $\begin{array}{c}\text { Interacting residue of } \\
\text { amino acid }\end{array}$ & $\begin{array}{c}\text { Distance, } \\
\mathbf{A}^{\circ} \\
\end{array}$ \\
\hline 03 & LYS-156 & 6.52 & $\begin{array}{c}\text { MET-380 } \\
\text { ILE-377 } \\
\text { ALA-311 } \\
\text { PRO-137 } \\
\end{array}$ & $\begin{array}{l}5.35 \\
5.29 \\
3.75 \\
5.43 \\
\end{array}$ \\
\hline 04 & $\begin{array}{l}\text { GLY } \\
\text { PHE } \\
\text { LYS } \\
\text { ASP } \\
\text { VAL }\end{array}$ & $\begin{array}{c}2.85 \\
2.54,2.6 \\
3.02 \\
3.61,3.6 \\
3.29\end{array}$ & $\begin{array}{c}\text { HIS } \\
\text { ARG } \\
\text { LYS }\end{array}$ & $\begin{array}{c}4.43,5.4 \\
4.39 \\
4.96\end{array}$ \\
\hline 05 & CYS-449 & 4.45 & $\begin{array}{c}\text { LEU-308 } \\
\text { GLY-451 } \\
\text { ALA-455 } \\
\text { LEU-310 } \\
\text { ILE-459 } \\
\text { PHE-442 } \\
\text { ALA-331 } \\
\text { PRO-133 }\end{array}$ & $\begin{array}{l}5.35 \\
3.85 \\
3.69 \\
5.38 \\
4.28 \\
4.44 \\
5.16 \\
5.02 \\
\end{array}$ \\
\hline 06 & PRO-67 & 3.45 & $\begin{array}{c}\text { ILE-68 } \\
\text { ILE-75 } \\
\text { LYS-79 } \\
\text { LYS-91 } \\
\text { ILE-64 } \\
\text { ALA-88 } \\
\text { PHE-84 } \\
\end{array}$ & $\begin{array}{c}3.58,4.4 \\
4.74 \\
4.51 \\
4.07 \\
5.31 \\
5.00 \\
4.17 \\
\end{array}$ \\
\hline 07 & $\begin{array}{l}\text { LYS-261 } \\
\text { LYS-141 }\end{array}$ & $\begin{array}{l}2.42 \\
2.85\end{array}$ & $\begin{array}{l}\text { ARG-133 } \\
\text { VAL-138 } \\
\text { ARG-258 }\end{array}$ & $\begin{array}{l}4.96 \\
4.04 \\
5.00\end{array}$ \\
\hline
\end{tabular}

\begin{tabular}{|c|c|c|c|c|}
\hline & \multicolumn{2}{|c|}{ Hydrogen bond } & \multicolumn{2}{|c|}{ Hydrophobic bond } \\
\hline $\mathbf{N}^{\circ}$ & $\begin{array}{c}\text { Interacting residue of } \\
\text { amino acid }\end{array}$ & $\begin{array}{c}\text { Distance, } \\
\mathbf{A}^{\circ} \\
\end{array}$ & $\begin{array}{c}\text { Interacting residue } \\
\text { of amino acid }\end{array}$ & \begin{tabular}{|c|} 
Distance, \\
$\mathbf{A}^{\circ}$ \\
\end{tabular} \\
\hline 08 & $\begin{array}{l}\text { ASP-254 } \\
\text { LYS-141 }\end{array}$ & $\begin{array}{l}3.57 \\
2.59\end{array}$ & $\begin{array}{c}\text { ARG-133 } \\
\text { ARG-258 } \\
\text { LYS-261 }\end{array}$ & $\begin{array}{l}3.97 \\
5.33 \\
3.16\end{array}$ \\
\hline 09 & Absent & Absent & $\begin{array}{c}\text { PHE-139 } \\
\text { ILE-450 } \\
\text { PRO-137 } \\
\text { LEU-308, LEU-159 } \\
\text { ALA-311 } \\
\text { ALA-311 } \\
\text { LYS-156 } \\
\text { ARG-382 } \\
\text { ALA-127 } \\
\text { HIS-447 }\end{array}$ & $\begin{array}{l}4.63 \\
5.17 \\
5.22 \\
5.24 \\
3.63 \\
5.22 \\
4.36 \\
3.54 \\
3.06 \\
5.30 \\
5.31 \\
\end{array}$ \\
\hline 10 & CYS-449 & 5.39 & $\begin{array}{l}\text { ALA-455 } \\
\text { ILE-377 } \\
\text { ILE-377 }\end{array}$ & $\begin{array}{c}4.16 \\
3.444 .60\end{array}$ \\
\hline 11 & $\begin{array}{l}\text { CYS-449 } \\
\text { PRO-441 }\end{array}$ & $\begin{array}{c}2.91,3.7 \\
3.23\end{array}$ & $\begin{array}{l}\text { ALA-455 } \\
\text { ALA-311 } \\
\text { ILE-377 }\end{array}$ & $\begin{array}{c}4.15 \\
3.48,5.0 \\
3.66,4.83\end{array}$ \\
\hline 12 & HIS-73 & 2.45 & $\begin{array}{c}\text { ILE-64 } \\
\text { LYS-91 } \\
\text { PHE-386 } \\
\text { ALA-88 } \\
\text { ALA-76 } \\
\text { ILE-75 } \\
\text { ILE-68 } \\
\end{array}$ & $\begin{array}{c}5.34 \\
4.13 \\
4.07,5.2 \\
3.68 \\
3.58 \\
3.64,4.4 \\
5.30 \\
\end{array}$ \\
\hline
\end{tabular}

\subsection{D interaction diagram and $\mathrm{H}$ bonding with bond distance}

Figure 4 illustrates the interaction of $\mathrm{H}$ bonding and hydrophobic bond for Bacillus cereus which is obtained from the discovery studio software including the protein code number marking various colors.

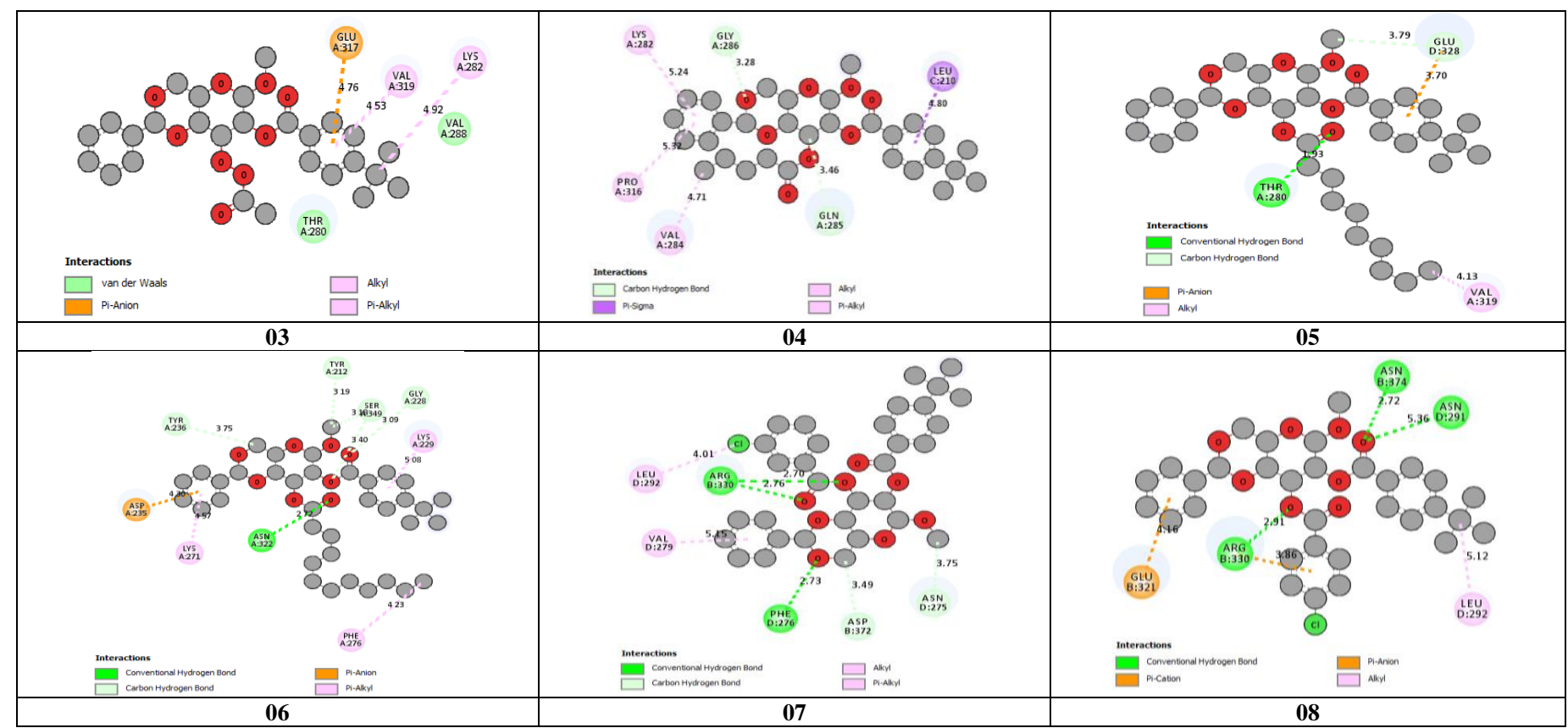




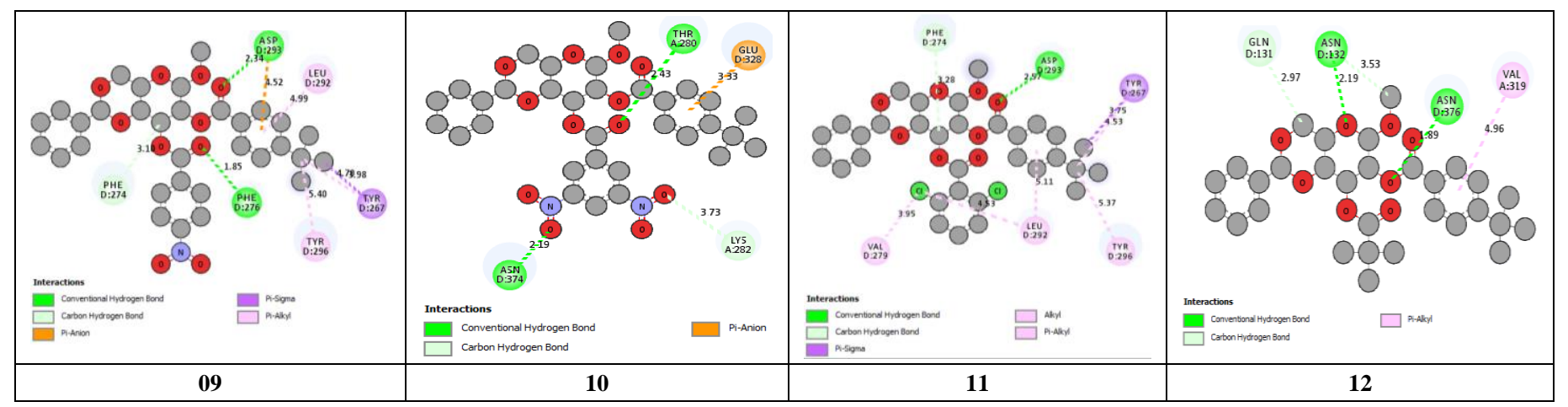

Figure 4. Interaction of $\mathrm{H}$ bonding and hydrophobic bond for Bacillus cereus

\subsection{Electrostatic potential (ESP) charge distribution}

The ESP map is a valuable factor and way to get the information for a molecule that the total charges, positive and negative, how is distributed through the molecule because it can say the possible site of ligands or protein attraction region, a promising site for an electrophilic attack site or nucleophilic attack site.
Figure 5 has been attached the 3D mapped of Electrostatic potential charge distribution where the light ash-green color is a negative charge and the reddish color is a positive charge. It is found that the negative charge region is higher than the positive charge region which indicates the more attraction the electrophilic groups in these molecules.
03

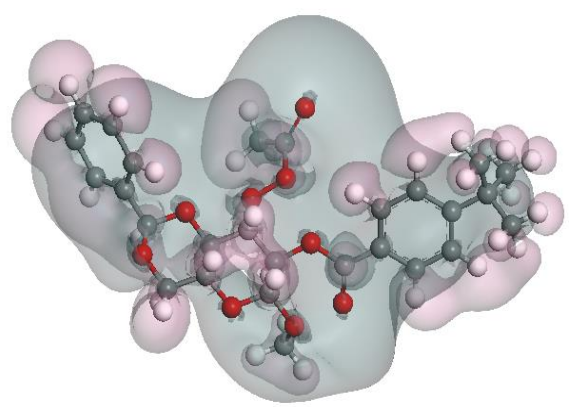

06

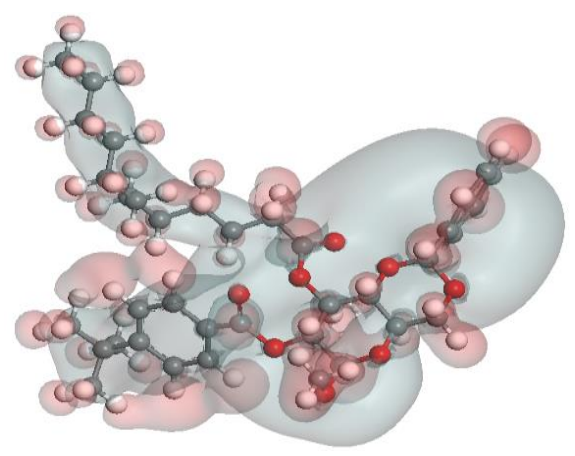

04

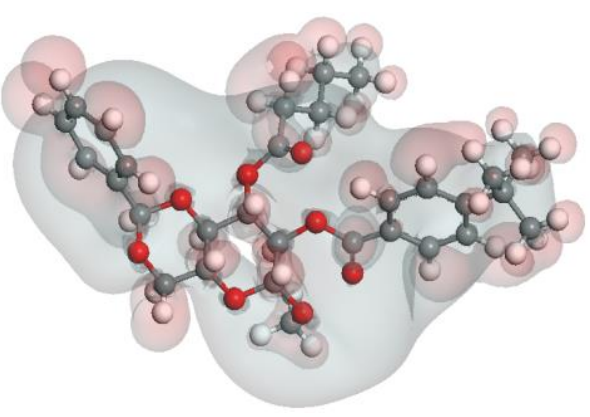

07

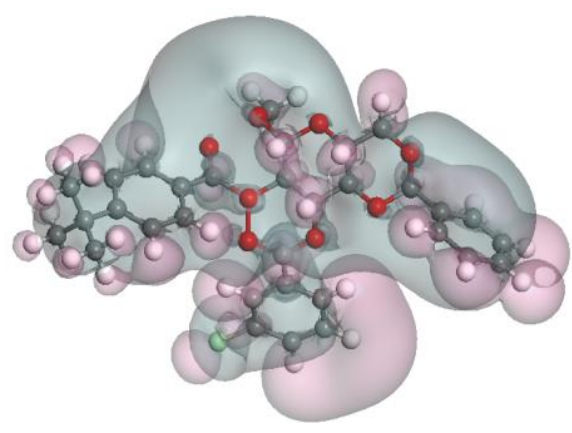

05

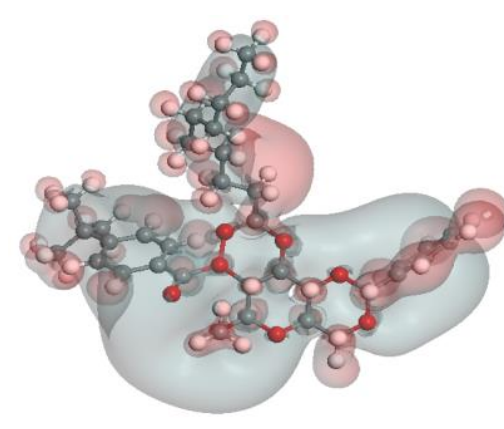

08

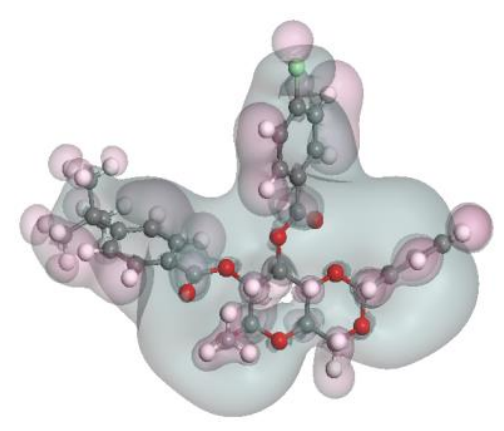

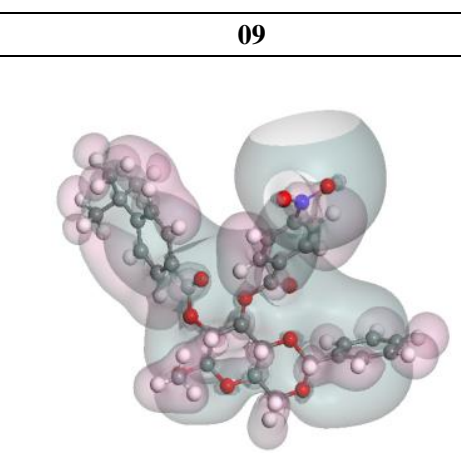

10

10
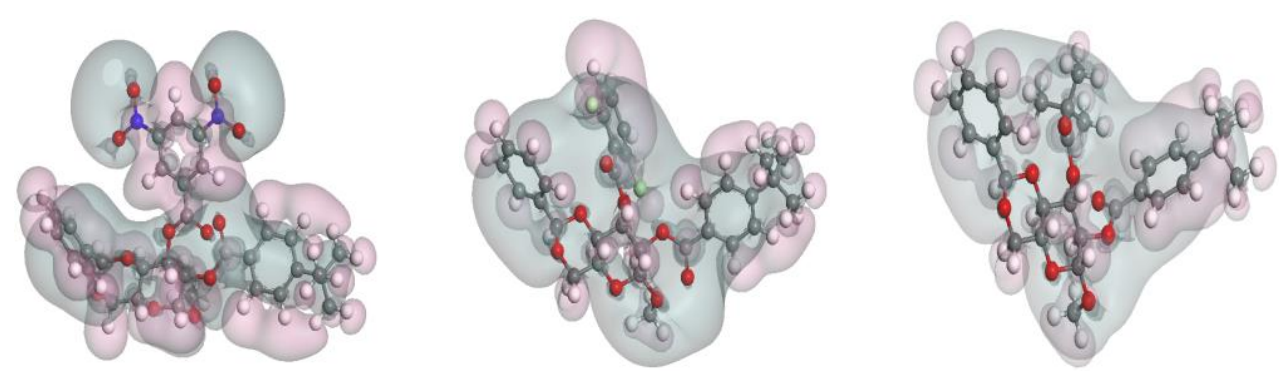

Figure 5. 3D mapped of Electrostatic potential charge distribution 


\section{CONCLUSIONS}

This study represents the computational investigation of methyl $\alpha$-Dglucopyranoside and its derivatives against bacteria, fungi and COVID-19 pathogens which lead to fill up a study gap and literature of computational study, besides it makes encouraging, accurate and fine investigated results. From the HOMO-LUMO gap, it can be said that the structural activity relationship is visible inside all these compounds, because the chain and benzene of these derivatives have changed and their chemical activity has undergone a major change in their skeleton. The molecular docking study illustrates detail information about binding affinity of ligand-protein interaction of tested compounds, and all compounds can perform very well against bacteria and fungi, even though they are more effective the COVID-19 virus than against bacteria and fungi. Regarding the autodock scoring, the sample of 09,07 and 10 can show the highest docking score against Covid-19. The unique and important aspect of this study, are the ADME and toxicity studies. All compounds have an adverse effect on aquatic and non-aquatic environments from toxicity data. So the most important point of this study can be highlighted in such a way that no matter how effective the drummer is, we need to handle these compounds properly before using them to protect the environment so that no harm is done to the environment.

\section{CONFLICT OF INTEREST}

The authors have no conflicts of interest to declare.

\section{ACKNOWLEDGMENTS}

We gratefully acknowledge financial support from the Ministry of Science and Technology (MOST), Government of Bangladesh (Grant no. 39.00.0000.09.06.79.2017/Phy's-437).

\section{REFERENCES}

1. P. K. Hohenberg, W, Phys. Rev.136, B864, (1964).

2. W. B. Kohn, D. Axel, Parr, G. Robert, J.Phys. Chem. 100, 12974-12980, (1996).

3. G. K. Sliwoski, K. Sandeepkumar, J. Meiler, W. E. Lowe, Pharmacol. Rev. 66, 334-395, (2014).

4. M. Zheng, L. Xian, X. Yuan, L. Honglin, L. Cheng, J. Hualiang, Trends pharmacol. sci. 34, 549-559, (2013).

5. Z. Afroza, K. Ajoy, S. M. Nuruzzaman, P. Sunanda, Int. J. Chem. Technol. 3, 151-161, (2019).

6. K. Ajoy, P. Sunanda, S. M. Nuruzzaman, M. I. Jahidul, Int. J. Chem. Technol. 6, 236-253, (2019).

7. M. I. Jahidul, S. M. Nuruzzaman, K. Ajoy; P. Sunanda, Int. J. Adv. Biol. Biomed. Res. 7, 318-337, (2019).

8. M. I. Jahidul, K. Ajoy, S. M. Nuruzzaman, P. Sunanda, Z. Afroza, Adv. J. Chemi. 2, 316-326, (2019).

9. M. J. Islam, S. M. Nuruzzaman, K. Ajoy, P. Sunanda, Int. J. Adv. Biol. Biomed. Res. 7, 318-337, (2019).

10. K. Ajoy, S. M. Nuruzzaman, P. Sunanda, Turkish Comp. Theo. Chem. 3(2), 59-68, (2019)

11. K. Ajoy, S. M. Nuruzzaman, P. Sunanda, Eurasian J. Environ. Res. 3, 1-10, (2019).

12. R. L. Andrew, Pearson Education Limited, 2001

13. J. G. Vinter, G. Mark, Mol. Model. drug design. Macmillan International Higher Education, (1994).

14. A. Daniel G. schwend, C. Andrew, I. D. Kuntz, J. Mol. Recognit. 9, 175-186, (1996).

15. W. P. Walters, M. A. Ajay, M. A. Murcko, Curr. Opin. Chem. Biol. 3, 384387, (1999).

16. H. C. Kolb, K. S. Barry, Drug Discov. Today. 8, 1128-1137, (2003).

17. L. H. Naylor, Biochem. Pharmacol. 58, 749-757, (1999).

18. H. V. D. Waterbeemd, G. Eric, Nat. Rev. Drug Discov. 2, 192-204, (2003).

19. 19. J. A. Arnott, S. L. Planey, Exp. Opin. Drug Discov. 7, 863-875, (2012).

20. K. Vimala, K. S. Samba, Y. M. Mohan, B. Sreedhar, K. M. Raju, Carbohydr. Polym. 75, 463-471, (2009).

21. C. Rafin, V. Etienne, M. Sancholle, D. Postel, C. Len, P. Villa, G. Ronco, J. Agric. Food Chem. 48, 5283-5287, (2000).

22. F. Cedeno-Laurent, J. O. Matthew, S. R. Barthel, D. Hays, T. Schatton, Q. Zhan, H. Xiaoying, K. L. Matta, J. G. Supko, M. H. Frank, J. Invest. Dermatol. 132, 410-420, (2012).

23. J. E. Barradas, M. I. Errea, N.B. D’Accorso, C. S. Sepúlveda, L. B. Talarico, E. B. Damonte, Carbohydr. Res. 343, 2468-2474, (2008).
24. L. Han, S. Wenlong, X. Li, A. Sik, H. Lin, K. Liu, L. Wang, Med. Chem. Comm. 10, 598-605, (2019).

25. L. Gómez-García, R.-M. Irma, M. Rodríguez-Sosa, L. I. Terrazas, Parasitol. Res. 99, 440-448, (2006).

26. E. Kerasioti, S. Dimitrios, A. Jamurtas, A. Kiskini, Y. Koutedakis, N Goutzourelas, S. Pournaras, A. M. Tsatsakis, D. Kouretas, Food chem toxicol. 61, 42-46, (2013).

27. T. K. Pal, D.Tuli, A. Chakrabarty, D. Dey, S. K. Ghosh, T. Pathak, Bioorg. Med. Chem. Lett. 20, 3777-3780, (2010).

28. M. Islam, M. Arifuzzaman, M. Rahman, M. A. Rahman, S. M. A. Kawsar, Hacett. J. Biol. Chem. 47, 153-164, (2019).

29. S. M. A. Kawsar, M. Islam, S. Jesmin, M. A. Manchur, I. Hasan, S. Rajia, Int. J. Biosci. 12, 408-416, (2018).

30. S. M. A Kawsar, A. K. M. S. Kabir, M. M. Manik, M. K. Hossain, M. N. Anwar, Int. J. Biosci, 2, 66-73, (2012).

31. A. Kabir, P. Dutta, M. N. Anwar, Pak. J. Biol. Sci. 7, 1730-1734, (2004).

32. A. D. Becke, J. Chem. phys. 96, 2155-2160, (1992).

33. R. G. Parr, Horizons of Quantum Chemistry, ed: Springer, 1980, pp. 5-15.

34. R. G. Parr, Y. Weitao, J. Am. Chem. Soc. 106, 4049-4050, (1984).

35. M. J. Frisch, G. W. Trucks, H. B. Schlegel, G. E. Scuseria, A. Robb, J. R. Cheeseman, G. Scalmani, V. Barone, B. Mennucci, G. A. Petersson, Gaussian 09. Gaussian Inc, Wallingford CT, 93, 2009.

36. W. J. Hehre, S. F. Robert, J. A. Pople, J. Chem. Phys. 51, 2657-2664, (1969).

37. C. Sosa, A. Jan, C. Lee, J. F. Blake, B. L. Chenard, T. W. Butler, Int. J. Quantum Chem. 49, 511-526, (1994).

38. W. L. DeLano, "The PyMOL user's manual," http://www.pymol.org, 2002.

39. O. Trott, O. J. Arthur, J. Comput. Chem. 31, 455-461, (2010).

40. A. S. Inc, "Discovery Studio Modeling Environment, release 4.0," 2013.

41. F. Cheng, L. Weihua, Y. Zhou, J. Shen, Z. Wu, G. Liu, P. W. Lee, Y. Tang, admetSAR: a comprehensive source and free tool for assessment of chemical ADMET properties, ed: ACS Publications, 2012.

42. A. Daina, M. Olivier, V. Zoete, "SwissADME: a free web tool to evaluate pharmacokinetics, drug-likeness and medicinal chemistry friendliness of small molecules," Sci. Rep. 7, 42717, (2017).

43. M. J. Islam, K. Ajoy, P. Sunanda, S. M. Nuruzaman, Chem. Methodol. 4, 130$142,(2020)$

44. A. Kumer, S. M. Nuruzaman, S. Paul, Turkish Comp. Theo. Chem. 3, 59-68, (2019).

45. R. G. Parr, C. K. Pratim, J. Am. Chem. Soc. 113, 1854-1855, (1991).

46. R. G. Parr, L. V. Szentpály, L. Shubin, J. Am. Chem. Soc. 21, 1922-24, (1999).

47. C. A. Lipinski, L. Franco, B. W. Dominy, J. P. Feeney, Adv. Drug Deliv. Rev. 23, 3-25, (1997).

48. N. J. Kumar, S. S. Mishara, H. P. Singh, S. Ranjan, C. S. Sharma. Int. J. Pharm. Sci. Drug Res. 10, 278-282, (2018).

49. M. M. Hoque, K. Ajoy, H. M. Sajib, K. M. Wahab, Int. J. Adv. Biol. Biomed. Res. 9, 77-104, (2021).

50. K. Fent, W. A. Anna, D. Caminada, Aquat. Toxicol. 76, 122-159, (2006) 